\title{
Oxidization of the mantle caused by recycling of sedimentary carbonates may contribute to the formation of iron-rich mantle melts
}

\author{
DETAO HE ${ }^{1}$, YONGSHENG LIU ${ }^{1}$, CHUNFEI CHEN ${ }^{2}$, \\ STEPHEN F. FOLEY ${ }^{2}$ AND MIHAI DUCEA ${ }^{3}$ \\ ${ }^{1}$ China University of Geosciences (Wuhan) \\ ${ }^{2}$ Macquarie University \\ ${ }^{3}$ University of Arizona \\ Presenting Author: detaohe@hotmail.com
}

Iron-rich mantle melts are of great importance for understanding mantle heterogeneity and the formation of some world-class ore deposits. However, the origin of iron-rich melts is debated: previous studies mainly focused on the chemical and mineral compositions of mantle sources, with little attention to the effect of melting conditions. We describe a peridotite xenolith from the Dalihu basalt, Inner Mongolia, China, which contains extremely forsterite-rich olivine $\left(\mathrm{Fo}_{98}\right)$ and minerals with high $\mathrm{Fe}^{3+} / \Sigma \mathrm{Fe}$ ratios, including magnesioferrite and hematite. This mineral assemblage records a strongly oxidizing environment. Coexisting carbonatitic xenoliths and increasing ${ }^{87} \mathrm{Sr} /{ }^{86} \mathrm{Sr}$ from core to rim of clinopyroxene in the peridotite suggest that the oxidizing environment may be caused by recycled sedimentary carbonate. Model calculation by pMELTS showed that melting of mantle peridotite at high $\mathrm{fO}_{2}$ can produce iron-rich melt with low $\mathrm{CaO}$ and $\mathrm{Al}_{2} \mathrm{O}_{3}$ contents, which is the geochemical signature of ferropicrite. Our findings also have implications for the origin of podiform chromitite, which contains widespread extremely forsteritic olivine $\left(\mathrm{Fo}_{99}\right)$ and high $\mathrm{Fe}^{3+}$ chromite $\left(\mathrm{Fe}^{3+} / \Sigma \mathrm{Fe}\right.$ up to 0.52 ). Since oxidization can form high-Mg\# olivine and high $\mathrm{Fe}^{3+} / \Sigma \mathrm{Fe}$ ratio phases at the same time, we infer that deep mantle recycling of carbonate sediments can locally produce a substantial increase in the $f \mathrm{O}_{2}$ of the mantle, and subsequent mantle melting may result in high-Mg\# olivine and high- $\mathrm{Fe}^{3+} / \Sigma \mathrm{Fe}$ ratio iron-rich melts, which eventually leads to the crystallization of chromite. 